\title{
PENGARUH KERELASIAN PEMASARAN DAN CITRA PERGURUAN TINGGI TERHADAP KEPERCAYAAN MAHASISWA PROGRAM DIPLOMA PADA SEKOLAH TINGGI ILMU ADMINISTRASI MANDALA INDONESIA DI JAKARTA
}

\author{
Nur Fitri Rahmawati \\ Institut Ilmu Sosial dan Manajemen STIAMI \\ nurfitri@stiami.ac.id
}

\begin{abstract}
Abstrak. Penelitian ini dilakukan untuk mengetahui kerelasian pemasaran program diploma STIAMI di Jakarta, mengetahui citra perguruan tinggi program diploma STIAMi di Jakarta, mengetahui kepercayaan mahasiswa program diploma STIAMI di Jakarta, dan mengetahui seberapa besar pengaruh kerelasian pemasaran dan citra perguruan tinggi secara parsial dan simultan terhadap kepercayaan mahasiswa program diploma STIAMI di Jakarta.

Populasi penelitian ini adalah Mahasiswa STIAMI Program Diploma yang berjumlah 465 orang dan yang dijadikan sampel penelitian ini adalah mahasiswa/mahasiswi program diploma STIAMI sejumlah 117 orang. Setiap responden diberikan sebanyak 32 pertanyaan dengan menggunakan skala likert.

Hasil penelitian ini menunjukkan bahwa kerelasian pemasaran berpengaruh positif dan signifikan terhadap kepercayaan mahasiswa, citra perguruan tinggi berpengaruh positif dan signifikan terhadap kepercayaan mahasiswa.
\end{abstract}

Kata Kunci: Kerelasian Pemasaran, Citra Perguruan Tinggi, Kepercayaan Mahasiswa

Abstract. This study was conducted to determine relationship marketing, imagery STIAMI college diploma program in Jakarta, Diploma Student's Trust and also determine how much influence of relationship marketing and college's image partially and simultaneously on Diploma Student's trust at STIAMI Jakarta.

The population was STIAMI's Diploma Student, amounting to 465 people and the researcher takes 117 among af the population be the sample. Each respondent was given a total of 32 questions using a Likert scale.

The results of this study indicate that relationship marketing gives the positive influence and significant to the Diploma student's trust, college's image gives positive and significant impact to the Diploma student's trust.

Keywords: Relationship Marketing , College's Image, Trust

\section{PENDAHULUAN}

Di era kompetisi sekarang ini, salah satu tantangan besar yang dihadapi lembaga perguruan tinggi adalah semakin ketatnya persaingan didalam mencari mahasiswa baru. Oleh karena itu, setiap perguruan tinggi semakin dituntut untuk mampu mengelola institusinya secara profesional dengan cara meningkatkan mutu pendidikan berikut mutu pelayanan pelanggan terbaik kepada seluruh stakeholders. Perguruan tinggi mempunyai stakeholder internal, yaitu mahasiswa, dosen, dan karyawan. Sedangkan stakeholders eksternal perguruan tinggi antara lain adalah pemerintah, organisasi profesi, dunia usaha dunia industri, lembaga pendidikan lain dan kelompok masyarakat lain yang relevan.

Tercapainya kepuasan stakeholders menjadi salah satu ukuran atau indikator keberhasilan pengelolaan. Model pengelolaan lembaga perguruan tinggi 
Nur Fitri Rahmawati, Pengaruh Kerelasian Pemasaran Dan Citra Perguruan Tinggi...

dapat disetarakan dengan model industri atau bisnis di bidang jasa. Meski dengan tujuan utamanya tidak boleh menyimpang dari amanat Undang-Undang Sistem Pendidikan Nasional, namun strategi pengelolaan dengan pendekatan manajemen bisnis jasa seperti membangun kerelasian pemasaran (marketing relationship) dan citra organisasi yang baik (corporate/institutional image) merupakan hal yang tak bisa dielakkan.

Produk jasa pendidikan di perguruan tinggi ditawarkan dalam bentuk rumpun program studi yang pengelolaannya dilakukan di bawah unit pengelola Jurusan/Program Studi. grafik dibawah ini :
Rumpun dan jumlah program studi sangat beragam dengan nomenklatur yang telah ditetapkan pemerintah, dimana dapat dikelompokkan dalam beberapa bidang ilmu antara lain bidang ekonomi, teknik, matematika dan ilmu pengetahuan alam, sastra dan bahasa, pendidikan, agama, dan seni.

Dalam beberapa tahun terakhir ini, terdapat fenomena peningkatan minat bagi pelajar lulusan sekolah tingkat atas (SMA/SMK/MA) untuk melanjutkan sekolah khususnya untuk peminatan pendidikan jenjang Diploma Tiga, sebagaimana khusus untuk wilayah Jakarta dapat dilihat dalam

Tabel 1

Jumlah Mahasiswa Kopertis Wilayah III

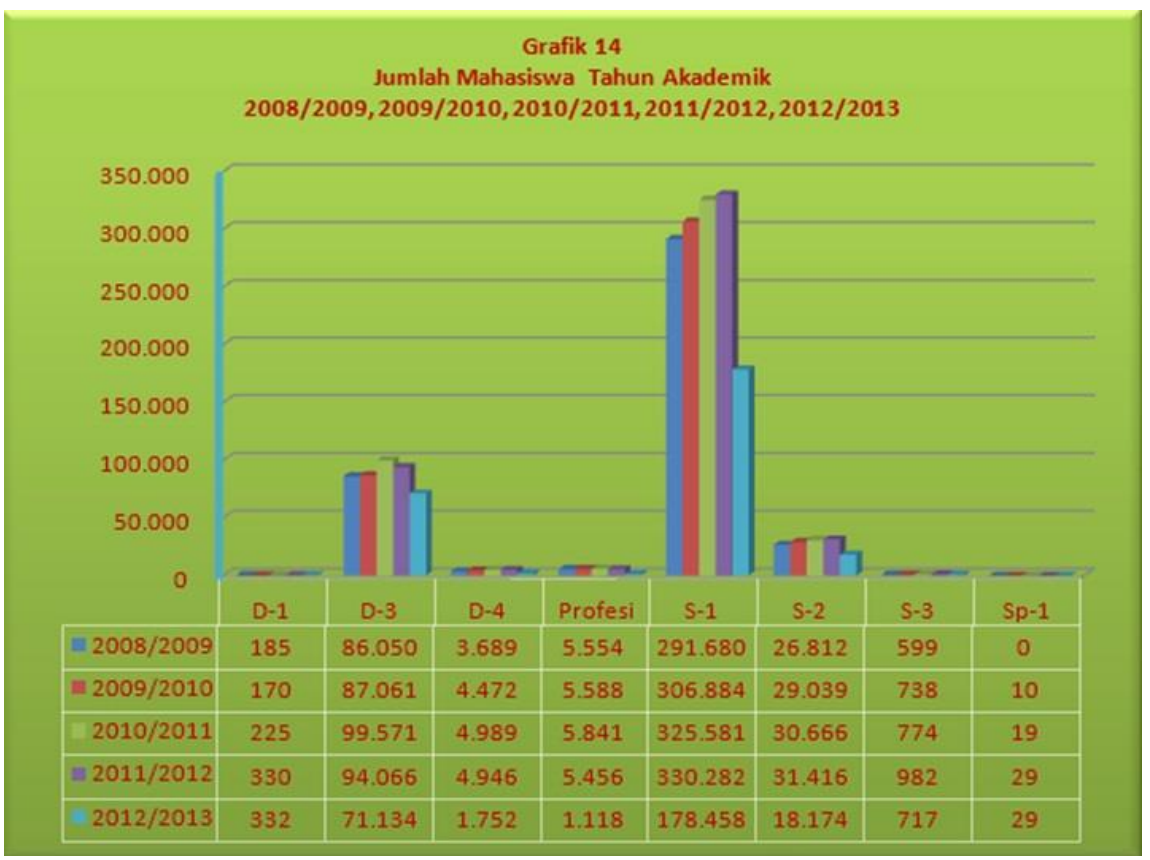

Sumber : Direktori Kopertis Wilayah III

Dari tabel 1 di atas, terdapat penurunan minat cukup signifikan di tahun akademik 2012/2013 terhadap pendidikan Diploma, yang hal tersebut dirasakan pula oleh Sekolah
Tinggi Ilmu Administrasi Mandala Indonesia jenjang Program Diploma tiga seperti di bawah ini :

Tabel 2

Mahasiswa Aktif Program Diploma

\begin{tabular}{|c|c|c|c|}
\hline \multicolumn{4}{|c|}{ Jumlah Mahasiswa Baru } \\
\hline $\mathbf{2 0 1 0}$ & $\mathbf{2 0 1 1}$ & $\mathbf{2 0 1 2}$ & $\mathbf{2 0 1 3}$ \\
\hline 101 Mahasiswa & 126 Mahasiswa & 122 Mahasiswa & 116 Mahasiswa \\
\hline
\end{tabular}

Sumber : STIAMI Program Diploma 
Adanya fenomena penurunan jumlah penerimaan mahasiswa baru jenjang Diploma Tiga Perguruan Tinggi STIAMI dalam tabel 2 di atas, selain karena persoalan eksternal yang bersifat makro, diduga kondisi internal juga memberikan pengaruh yaitu nilai manfaat yang dirasakan mahasiswa belum sesuai dengan harapan mereka. Masih terdapat beberapa kelemahan dalam kinerja penyelenggaraan program pendidikan di STIAMI untuk jenjang Diploma Tiga, yang diduga dipengaruhi beberapa faktor berikut seperti kurikulum masih belum sepenuhnya mengacu pada kebutuhan pasar kerja, kinerja pelayanan belum berjalan optimal, lokasi kampus cenderung sulit dijangkau, fasilitas pendukung belum memadai, penyerapan lulusan yang tergolong lambat, atau promosi yang dilaksanakan selama ini belum dapat membangun good image sebagai kampus pilihan di mata masyarakat. Jika kondisi tersebut terus berlangsung dan tidak dibenahi dengan segera, akan berakibat semakin menurunnya jumlah penerimaan mahasiswa baru Diploma Tiga dari tahun ke tahun.

Kopertis Wilayah III tergolong memiliki tingkat persaingan perguruan tinggi yang paling ketat. Karena banyaknya pilihan, konsekuensinya adalah masyarakat DKI Jakarta harus lebih kritis dan selektif dalam memilih perguruan tinggi yang dimasukinya. Disamping itu, banyaknya perguruan tinggi asing yang mulai membuka cabang di Indonesia khususnya di Jakarta tentu mengarah kepada terciptanya persaingan yang semakin berat.

Untuk dapat menghadapi tantangan yang dihadapi perguruan tinggi STIAMI tersebut, maka diperlukan upaya untuk melihat dan mengukur kinerja kerelasian pemasaran (marketing relationship) dan citra perguruan tinggi menurut persepsi mahasiswa selama ini sebagai konsumen utama untuk dapat mempertahankan dan meningkatkan kepercayaan mahasiswa terhadap penyelenggaraan pendidikan tinggi jenjang program Diploma Tiga yang ada di perguruan tinggi STIAMI

\section{Perumusan Masalah}

(1) Bagaimanakah kerelasian pemasaran perguruan tinggi program diploma STIAMI?, (2) Bagaimanakah citra perguruan tinggi program diploma STIAMI?, Bagaimanakah kepercayaan mahasiswa terhadap perguruan tinggi program diploma STIAMI?, (4) Seberapa besar kerelasian pemasaran dan citra perguruan tinggi berpengaruh terhadap kepercayaan mahasiswa program diploma STIAMI baik secara parsial maupun simultan?

\section{Manfaat Penelitian}

Penelitian ini diharapkan dapat memberi sumbangan pemikiran bagi manajemen perguruan tinggi STIAMI khususnya unit pengelola pendidikan jenjang Diploma Tiga untuk memperkuat efektivitas program Marketing Relationship dan Good Image kepada para stakeholders. Penelitian ini diharapkan dapat dijadikan bahan evaluasi untuk melihat tingkat kepercayaan mahasiswa kepada penyelenggaraan program Diploma Tiga di STIAMI.

\section{KAJIAN LITERATUR}

\section{Manajemen Pemasaran Jasa}

Menurut Kotler (2006), Manajemen Pemasaran adalah seni dan ilmu untuk memilih pasar serta mendapatkan, mempertahankan, dan menambah jumlah pelanggan melalui penciptaan, penyampaian, dan pengkomunikasian nilai pelanggan yang unggul. Swastha (2008:7) berpendapat bahwa, "Manajemen Pemasaran adalah penganalisaan, perencanaan, pelaksanaan, dan pengawasan program-program yang ditujukan untuk mengadakan pertukaran dengan pasar yang dituju dengan maksud untuk mencapai tujuan organisasi dalam memenuhi kebutuhan dan keinginan pasar tersebut serta menentukan harga, mengadakan komunikasi dan distribusi yang efektif untuk memberitahu, mendorong, serta melayani pasar". Sedangkan menurut Alma dalam bukunya Manajemen Pemasaran dan Pemasaran jasa (2009), yang dimaksud dengan Manajemen Pemasaran adalah kegiatan menganalisa, merencanakan, 
Nur Fitri Rahmawati, Pengaruh Kerelasian Pemasaran Dan Citra Perguruan Tinggi...

mengimplementasikan dan mengawasi segala kegiatan (program), guna memperoleh tingkat kegiatan yang menguntungkan dengan pembeli sasaran dalam rangka mencapai tujuan organisasi.

Adapun mengenai Pemasaran Jasa, perlu diketahui terlebih dahulu esensi daripada 'Jasa' itu sendiri, yaitu sebagai suatu kegiatan ekonomi yang outputnya bukan produk dikonsumsi bersamaan dengan waktu produksi namun memberikan nilai tambah (seperti kenikmatan, hiburan, santai, sahat) yang bersifat tidak berwujud (Zeithaml \& Mary Jo Bitner, 2000).

Menurut Kotler (2008: 231) menyatakan bahwa, "Pengertian jasa adalah setiap tindakan atau kegiatan yang dapat ditawarkan oleh suatu pihak kepada pihak lain, yang pada dasarnya tidak berwujud dan tidak dapat mengakibatkan kepemilikan apapun. Produksinya dapat dikaitkan atau tidak dikaitkan pada suatu produk fisik." Sedangkan menurut Adrian Payne dalam Yazid (2005) menyatakan bahwa Jasa sebagai aktivitas ekonomi yang mempunyai sejumlah elemen (nilai dan manfaat) intangible yang berkaitan dengannya, yang melibatkan sejumlah interaksi dengan konsumen atau barang-barang milik, tetapi tidak menghasilkan transfer kepemilikan. Perubahan dalam Kondisi ini bisa saja muncul dan produksi suatu jasa bisa memiliki atau bisa juga tidak mempunyai kaitan dengan produk fisik.

Bauran pemasaran atau yang dikenal dengan sebutan marketing mix adalah konsep dasar dalam pemasaran modern dengan kombinasi dari beberapa variabel utama atau dimensi yang dipergunakan sebagai landasan dalam penyusunan program serta strategi pemasaran, termasuk pemasaran jasa yang memiliki bauran dan dimensi lebih kompleks bila dibandingkan bauran pemasaran produk. Untuk memahami tentang bauran pemasaran diperlukan beberapa definisi bauran pemasaran menurut para ahli yang berbeda, sehingga diharapkan ada suatu wawasan yang luas yang dapat kita pegang sebagai dasar pemikiran.

Menurut Tjiptono (2005 : 31) bauran pemasaran jasa dapat dirangkum menjadi delapan, yaitu:
1) Product, yaitu bentuk penawaran organisasi jasa yang ditujukan untuk mencapai tujuan organisasi melalui pemuasan kebutuhan dan keinginan pelanggan.

2) Pricing, yaitu keputusan bauran harga berkenaan dengan kebijakan- kebijakan strategis dan taktis, seperti tingkat harga di antara berbagai kelompok pelanggan.

3) Promotion, yaitu berbagai metode untuk mengkomunikasikan manfaat jasa kepada pelanggan potensial dan aktual.

4) Place, yaitu menyangkut kemudahan akses terhadap jasa bagi para pelanggan potensial.

5) People, yiatu orang-orang yang terlibat dalam penyediaan jasa. Faktor People merupakan unsur vital dalam bauran jasa.

6) Physical Evidence, yaitu karakteristik intangible pada jasa yang menyebabkan pelanggan potensial tidak bisa menilai jasa sebelum mengkonsumsinya.

7) Process, yaitu proses produksi/operasi yang berlangsung sebagi salahsatu faktor penting bagi konsumen dimana high contact service seringkali berperan sebagai coproducer jasa yang bersangkutan.

8) Customer Service, yaitu layanan pelanggan sebagai kualitas total yang dipersepsikan oleh pelanggan.

Menurut Kotler dan Keller (2006:441), jasa memiliki empat ciri utama yang sangat mempengaruhi rancangan program pemasaran jasa, yaitu :

1) Tidak berwujud (Intangibility), dimana Jasa mempunyai sifat tidak berwujud karena tidak bisa dilihat, dirasakan, diraba, didengar, atau dicium sebelum ada transaksi pembelian. Untuk mengurangi ketidakpastian, pembeli akan mencari tanda atau bukti dari kualitas layanan jasa tersebut. Pembeli akan mengambil kesimpulan mengenai kualitas layanan jasa dari tempat (place), manusia (people), peralatan (equipment), alat komunikasi (communication material), simbol-simbol (symbols) dan harga (price) yang mereka lihat.

2) Tidak dapat dipisahkan (Inseparability), dimana Jasa pada umumnya diproduksi 
secara khusus. Jika jasa di-delivery oleh seseorang, maka orang tersebut merupakan bagian dari layanan jasa tersebut. Client juga hadir padsa saat jasa diberikan, interaksi penyedia dengan client merupakan ciri khusus dari pemasaran jasa, baik penyedia maupun client akan mempengaruhi hasil jasa tersebut.

3) Beraneka Ragam (Variability), dimana Jasa tergantung kepada yang menyediakannya, kapan dan dimana disediakan. Seringkali pembeli jasa menyadari akan keanekaragaman ini dan membicarakannya dengan yang lain sebelum memilih seorang penyedia jasa.

4) Tidak Tahan Lama (Perishability), dimana Jasa mempunyai sifat tidak dapat disimpan. Keadaan tidak tahan lama dari Jasa bukanlah masalah jika permintaannya stabil, karena mudah untuk melakukan persiapan pelayanan sebelumnya Jika permintaan terhadapnya berfluktuasi maka perusahaan jasa menghadapi masalah yang sulit.

\section{Kerelasian Pemasaran (Relationship Marketing)}

Relationship Marketing (Kerelasian Pemasaran) adalah konsep pemasaran yang mengalami perubahan yang berasal dari konsep transaction marketing sebagaimana dikemukakan oleh beberapa ahli. Di balik penciptaan transaksi jangka pendek, pemasar perlu membangun hubungan jangka panjang dengan pelangan yang bernilai, distributor, pedagang dan penyalur. Mereka membangun kekuatan ekonomi dan ikatan sosial dengan menjanjikan dan secara konsisten menghasilkan produk dengan kualitas tinggi, pelayanan yang baik dan harga yang wajar.

Kerelasian Pemasaran merupakan kombinasi dari proses bisnis dan teknologi yang tujuannya untuk memahami pelanggan dari berbagai prospektif untuk membedakan produk dan jasa institusi pendidikan secara kompetitif (Tiwana, 2001: 23). Nykamp (2001) mendefinisikan Kerelasian Pemasaran sebagai suatu upaya dalam menghasilkan nilai optimal bagi para pelanggan melalui bagaimana cara institusi pendidikan berkomunikasi dengan pelanggan, bagaimana institusi pendidikan memasarkannya, dan bagaimana institusi pendidikan melayani mereka, serta melalui media tradisional yang meliputi produk, harga, promosi dan distribusi.

Adapun fokus dari kerelasian marketing itu sendiri adalah untuk memperbaiki tingkat kepuasan pelanggan, meningkatkan loyalitas pelanggan yang ada, dalam menghadapi tingginya tingkat persaingan, globalisasi dan perputaran pelanggan serta perkemnbangan biaya pengakuisisian pelanggan. Dengan diterapkannya kerelasian pemasaran, memungkinkan institusi pendidikan untuk memliki kapabilitas untuk memahami perilaku pembelian pelanggan yang lebih baik dan untuk menentukan tipe komunikasi yang bagaimana yang seharusnya dijalankan dalam menghadapi pelanggan.

Konsep kerelasian pemasaran dalam jasa pendidikan, penekanan terletak pada interaksi antara institusi pendidikan dengan berbagai jaringan hubungan, tidak hanya dengan konsumen tetapi dengan semua pihak yang relevan terhadap institusi pendidikan. Good Relationship adalah aset yang paling mendasar bagi suatu institusi pendidikan melebihi apapun juga karena hubungan menentukan masa depan eksistensi institusi pendidikan. Karena itu pengembangan dari kerelasian pemasaran merubah paradigma pemasaran mulai dari persaingan dan konflik sampai kepada kerjasama yang saling menguntungkan, serta independen dan saling ketergantungan. 
Nur Fitri Rahmawati, Pengaruh Kerelasian Pemasaran Dan Citra Perguruan Tinggi...

Gambar 1

Transactional and Relationship Marketing

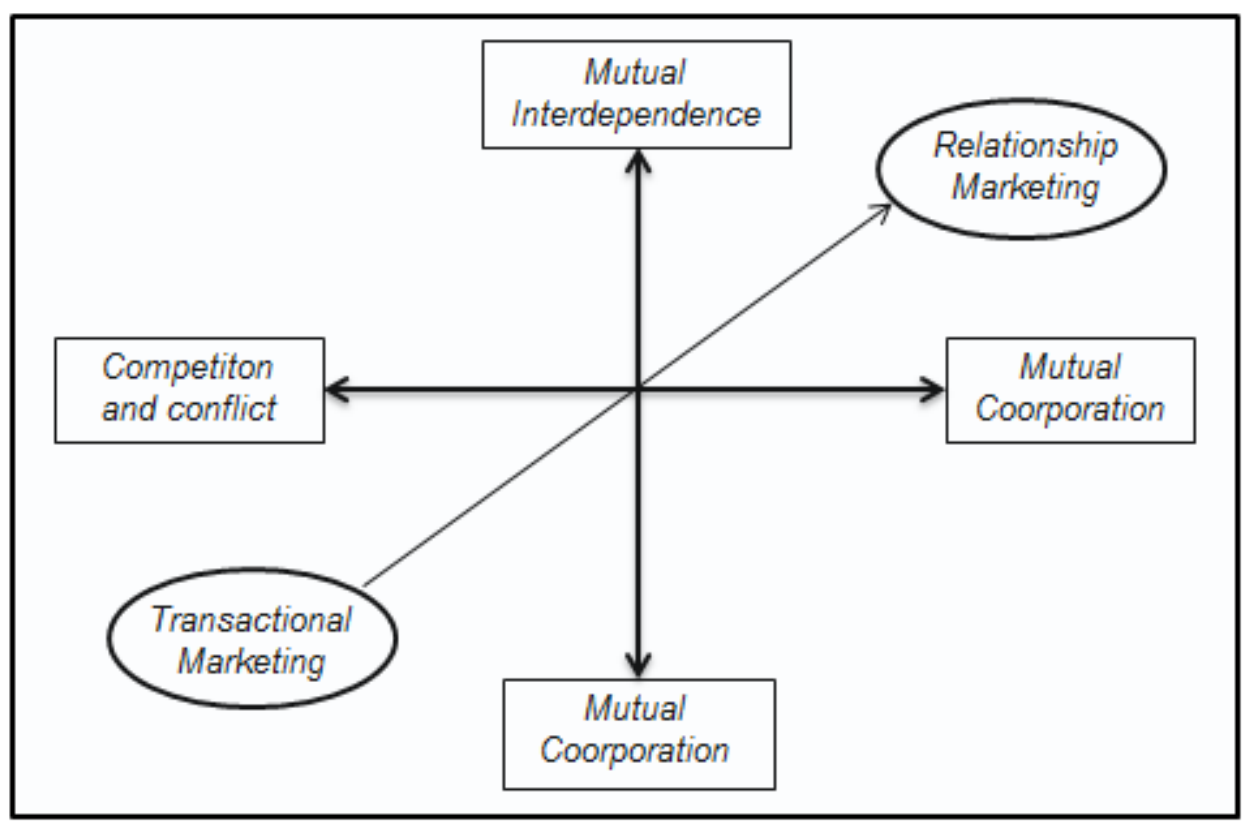

Sumber : Svend Hollensen, 2003 Marketing Management : A Relationship Approach, p. 11, Prentice Hall, Essex.

Dari gambar 1 di atas, dapat dilihat bahwa kerelasian pemasaran lebih menekankan kepada kerjasama daripada kompetisi dan konflik diantara para pemasar. Konsep ini berdasarkan kepada pembentukan nilai antara institusi pendidikan dengan pihak-pihak yang berkepentingan kepada institusi pendidikan. Dalam hal ini kerjasama sangat dibutuhkan untuk menciptakan untuk menciptakan nilai tersebut. Pada pendekatan pemasaran transaksional, penekanan terletak pada pasar dimana para pelanggan tidak diketahui. Tujuannya agar pelanggan memilih satu merek tertentu diantara berbagai macam merek yang ada. Hal ini menyebabkan timbulnya persaingan antara para pemasar dengan konsumen.

Menurut Donaldson dan O'Toole (2002 : 7) karakteristik yang membedakan antara berbagai jenis pertukaran adalah dengan menilai apakah pertukaran tersebut didasarkan atas transaksi pasar atau pertukaran relasional. Konsep dasar dari pertukaran ini, baik proses penciptaaan, pemeliharaan serta pemberhentian, merupakan hal penting dalam memahami pemasaran hubungan.
Pertukaran yang terjadi hanya satu kali merupakan suatu transaksi, tetapi apabila pertukaran tersebut terjadi berulangkali maka dapat menimbulkan suatu hubungan seperti dijelaskan pada Gambar 2 berikut:

Dalam menjalin suatu hubungan, institusi pendidikan harus mengetahui karakteristik tertentu yang dibutuhkan untuk membuktikan bahwa suatu hubungan itu eksis sehingga dapat memberikan sumbangan yang positif terhadap hubungan tersebut. Menurut hollensen (2003: 211) terdapat dimensi kunci dalam membangun sebuah hubungan, yaitu (1) ikatan, yang merupakan bagian dari suatu hubungan di mana kedua pihak membentuk suatu kesatuan untuk mencapai tujuan; (2) kepercayaan, yaitu suatu keyakinan dimana masing-masing pihak akan menepati janjinya dan tidak akan merugikan pihak lainnya; (3) empati, yaitu dimensi dari hubungan bisnis yang memungkinkan kedua pihak melihat situasi dari sudut pandang pihak lawannya yang dapat diartikan sebagai usaha memahai hasrat dan keinginan seseorang; dan yang terakhir adalah (4) resiprokal, yaitu di mana kedua pihak saling memberikan sesuatu yang menguntungkan keduanya. 
Gambar 2

Behavioural Spectrum of Relationships

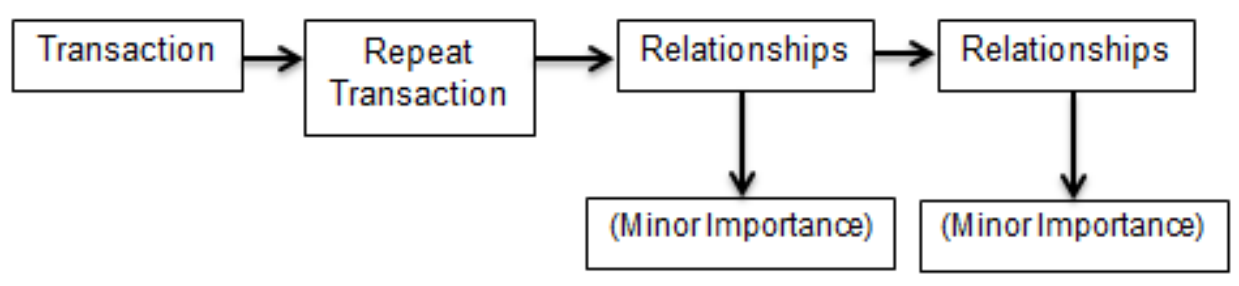

Sumber : Bill Donaldson and Tom O’Toole, 2002, Strategic Marketing Relationships, ohn Willey and Sons, New York.

Semakin berjalannya waktu, konsep kerelasian pemasaran mengalami perkembangan pesat. Gummesson dikutip dalam Tjiptono (2005: 27), menyebutkan dengan term Total Relationship Marketing (TRM). Konsep ini menyatakan bahwa kerelasian pemasaran merupakan pemasaran yang didasarkan atas interaksi antara berbagai jaringan hubungan, yang terdiri dari 30 hubungan.

Dalam teorinya, Gummesson membagi total relationship marketing dalam dua kategori besar, yaitu market relationships dan non market relationships. Market relationship merupakan hubungan antar supplier, pelanggan, pesaing dan mereka yang beroperasi di pasar. Market relationships dibagi menjadi classic market relationship yaitu hubungan antara supplier dengan pelanggan, hubungan antara supplierpelanggan-pesaing serta jaringan distribusi fisik, yang diperlakukan secara ekstensif dalam teori pemasaran secara umum. Yang kedua adalah special market relationships yang menggambarkan aspek-aspek khusus seperti interaksi dalam service encounter atau pelanggan sebagai suatu anggota dari program loyalitas. Kategori kedua adalah non market relationships yang secara tidak langsung mempengaruhi keefisienan dari market relationships. Terdiri dari mega relationships yang memperhatikan masalah ekonomi dan sosial secara umum, yaitu mega marketing (lobbying, opini public, dan kekuatan politik), mega alliances (contohnya NAFTA) dan social relationships (seperti persahabatan dan ikatan etnik).

Konsep kerelasian pemasaran menekankan pada pelanggan karena dalam hal ini pelanggan dianggap sebagai ujung tombak suatu usaha. Seiring dengan berubahnya dinamika bisnis saat ini maka peran konsumen semakin terlibat dalam komunikasi yang aktif dan eksplisit dengan institusi pendidikan sebagai penghasil produk atau jasa tersebut. Yang lebih penting lagi, saat ini komunikasi tersebut tidak lagi dikendalikan oleh institusi pendidikan. Konsumen secara individu dapat mengetahui dan mempelajari institusi pendidikan yang ia hadapi dengan pengetahuan mereka sendiri atau dari pengetahuan konsumen lain dari institusi pendidikan tersebut. Oleh karena itu kini konsumen telah berubah dari audiens menjadi pemain diatas panggung.

Pelanggan merubah dinamika dari pasar yang ada di mana konsumen berperan secara aktif dalam menciptakan nilai. Paradigma baru ini menyebabkan meningkatnya peran konsumen sebagai sumber kompetensi baru bagi institusi pendidikan. Kompetensi yang dimiliki pelanggan ini adalah pengetahuan dan keahlian, kemauan untuk belajar dan bereksperimen, serta kemampuan terlibat dalam komunikasi yang aktif dengan institusi pendidikan.

\section{Citra (Image)}

Ada pepatah mengatakan bahwa citra merupakan poin awal untuk sukses dalam pemasaran. Citra tidak dapat dibuat seperti 
Nur Fitri Rahmawati, Pengaruh Kerelasian Pemasaran Dan Citra Perguruan Tinggi...

barang dalam suatu pabrik, akan tetapi citra adalah kesan yang diperoleh sesuai dengan pemahaman dan pengetahuan seseorang terhadap sesuatu. Citra yang ada pada perusahaan terbentuk dari bagaimana perusahaan tersebut melakukan aktivitas kegiatannya dalam memenuhi kebutuhan dan pelayanan pelanggan. Suatu perusahaan harus mampu mengukur dan mengevaluasi, seperti apakah citra yang ada terbentuk dalam benak atau pandangan masyarakat. Citra atau Kesan biasanya dibentuk berdasarkan impresi atau pengalaman yang ditemukan oleh seseorang terhadap sesuatu, sehingga pada akhirnya membangun suatu sikap mental. Frank Jefkins (Soemirat, 2004) mengemukakan bahwa citra adalah kesan yang diperoleh berdasarkan pengetahuan dan pengertian seseorang tentang fakta-fakta atau kenyataan. Adapun sikap mental yang terbangun akan berfungsi sebagai alat pertimbangan untuk mengambil keputusan karena citra dianggap mewakili totalitas pengetahuan seseorang terhadap sesuatu.

Menurut Alma (2009) citra adalah kesan, impresi, perasaan atau konsepsi yang ada pada publik mengenai perusahaan, mengenai suatu obyek, orang atau lembaga. Dowling mendefinisikan citra sebagai "the total impression an entity makes on the mind of people”. Demikian juga Paul R .Smith (1995 : 332) "Corporate image is the sum of peoples perceptions of an organization image and perceptions are created trough all serce: sight, sound, smell, touch, taste and feeling experienced through product usage, customer service, the commercial environment and corporate communication, it is straghtly a result of everything a company does or does not do". (Boyle, 1996: 56).

Gronroos dalam Sutisna (2001: 332), mengidentifikasi empat peran citra bagi suatu organisasi yaitu sebagi berikut: :

1) Citra menceritakan harapan bersama dengan kampanye pemasaran eksternal seperti periklanan, penjualan pribadi dan kounikasi dari mulut ke mulut. Citra mempunyai dampak pada adanya pengharapan. Citra yang positif lebih memudahkan bagi organisasi untuk berkomunikasi secara efektif, dan membuat orang-orang lebih mudah mengerti dengan komunikasi dari mulut ke mulut. Tentu saja citra yang negative mempunyai dampak sebaliknya. Sedangkan citra yang netral atau tidak diketahui mungkin tidak menyebabkan kehancuran tetapi hal itu tidak membuat komunkasi dari mulut ke mulut berjalan lebih efektif.

2) Citra sebagai penyaring yang mempengaruhi persepsi pada kegiatan institusi pendidikan. Jika citra baik, maka citra menjadi pelindung. Perlindungan hanya efektif pada kesalahan-kesalahan kecil pada kualitas teknis dan fungsional, artinya jika terdapat kesalahan kecil dalam fungsi suatu produk, citra masih mampu menjadi pelindung dari kesalahan tersebut. Namun, jika kesalahan-kesalahan kecil terlalu sering terhadap maka citra akan berubah menjadi negative dan akan menimbulkan ketidakpuasan pada konsumen.

3) Citra adalah fungsi dari pengalaman dan harapan consumen. Ketika konsumen membangun harapan dan realitas pengalaman dalam bentuk kualitas pelayanan teknis dan fungsional, kualitas pelayanan yang dirasakan menghasilkan perubahan citra. Jika kualitas pelayanan yang dirasakan memenuhi citra atau melebihi citra, citra akan mendapat penguatan dan bahkan meningkat begitu pula sebaliknya.

4) Citra mempunyai pengaruh penting pada pemasaran. Citra organisasi yang kurang nyata dan jelas kemungkinan banyak akan mempengaruhi sikap karyawannya, dan juga pada hubungan dengan konsumen serta persepsi kualitas. Sebaliknya, citra yang jelas dan positif, misalnya citra organisasi dengan pelayanan yang sangat baik, secara internal menceritakan nilai-nilai yang jelas dan akan menguatkan sikap positif terhadap organisasi.

Masih menurut pandangan Gronroos, terdapat 4 (empat) jenis citra yang dapat dibentuk oleh seseorang atau organisasi, yaitu : 1) Corporate Image, sebagai citra yang melekat pada institusi apakah citra itu baik ataupun buruk. Citra institusi pendidikan yang positif akan memberikan dampak yang positif 
pula bagi institusi pendidikan, misalnya meningkatkan motivasi kerja para karyawannya, 2) Industry Image, dimana beberapa institusi organisasi saling bekerjasama untuk meningkatkan citra industrinya. Dunia bisnis pada umumnya berusaha membentuk sikap masyarakat yang lebih mendukung terhadap bisnis, 3) Area Image yaitu citra wilayah yang melekat pada suatu daerah, kota atau Negara. Citra wilayah biasanya berdampak pada sektor pariwisata dan perdagangan, 4) Individual Image yaitu citra yang melekat pada seseorang. Pada dasarnya setiap orang memiliki citra dirinya. (Sutisna, 2001: 356)

\section{Kepercayaan Pelanggan (Customer Trust)}

Kotler \& Keller (2009) memberikan pandagangan pentingnya bagaimana membangun kepercayaan dan keyakinan pelanggan. Organisasi harus menyediakan nilai-nilai pada produk/jasa yang diberikan dengan unsur-unsur kepercayaan yang kuat kepada para pelanggannya. Menurut Morgan dan Hunt (1994) bahwa kepercayaan terbentuk bila satu pihak mempunyai keyakinan dan merasa aman (confidence) atas integritas dan kehandalan mitra pertukarannya. Definisi ini selaras dengan definisi yang disusun oleh Moorman, Deshpande dan Zaltman (1993 : 82) bahwa "kepercayaan didefinisikan sebagai kesediaan untuk menyandarkan diri pada mitra pertukaran di mana seseorang merasa yakin dan aman". Kedua definisi ini diturunkan dari pandangan klasik yang menyatakan bahwa kepercayaan adalah "sebuah harapan yang digeneralisasikan yang dipegang seseorang, bahwa perkataan orang lain dapat diandalkan".

Dari definisi di atas menunjukkan betapa pentingnya factor confidence. Literatur tentang kepercayaan (trust) menyatakan bahwa confidence pada pihak yang dapat dipercaya merupakan hasil dari keyakinan individual atau organisasi bahwa pihak yang dapat dipercaya mempunyai integritas tinggi dan handal yang berhubungan dengan berbagai kualitas lain seperti konsisten, kompeten, jujur, adil, bertanggung jawab, bersifat membantu dan ramah.

Kepercayaan dianggap sebagai hal yang penting untuk menjaga hubungan dan meningkatkan hubungan dan mengurangi persepsi resiko secara efektif. Kepercayaan juga dianggap sebagai pondasi hubungan interpersonal sebagai prasyarat untuk kerjasama dan sebagai dasar untuk stabilitas hubungan dalam institusi sosial dan pasar.

Beberapa situasi dan indicator dari trust dikatakan oleh Mitchell dalam Egan (2001) sebagai berikut:

1. Probity (focus kepada kepercayaan dan integritas dan reputasi)

2. Equity (berkaitan dengan fair-mindedness, benevolence)

3. Realibility (berkaitan dengan kehandalan dan ketepatan serta konsistensi dari produk atau servis yang diharapkan dalam beberapa hal berkaitan dengan garansi yang dikeluarkan oleh perusahaan).

Jika perusahaan dapat menunjukkan trustworthy kepada konsumen, makan konsumen akan percaya kepada produk/jasa yang ditawarkan. Griffin (1995) mengatakan bahwa apa yang ada dalam pikiran konsumen pada saat ingin mengadakan transaksi adalah apakah organisasi dapat dipercaya. Kasper (1999) mengutarakan bahwa untuk bisnis jasa, customer sering menginginkan untuk mempunyai partner yang dapat dipercaya (trust) dan memperhatikannya. Hal ini akan memberikan hubungan yang lebih personal, dan dalam situasi ekstrim dikatakan one-onone personal contact. Lihat Tabel 3.

\section{METODE PENELITIAN}

\section{Jenis Penelitian}

Penelitian ini menggunakan metode survei dengan pendekatan korelasional untuk melihat besarnya pengaruh variabel bebas terhadap variabel terikat. Variabel bebas yang dimaksud yaitu X1 (Kerelasian Pemasaran), X2 (Citra Perguruan Tinggi), sedangkan variabel terikat yaitu Kepercayaan Mahasiswa terhadap Perguruan Tinggi Program Diploma STIAMI. 
Nur Fitri Rahmawati, Pengaruh Kerelasian Pemasaran Dan Citra Perguruan Tinggi...

Tempat dan Waktu Penelitian

Penelitian ini dilaksanakan di Sekolah Tinggi Ilmu Administrasi Mandala Indonesia
(STIAMI) Program Diploma Jakarta yang dilakukan dari bulan Januari 2014 sampai dengan Maret 2014.

Tabel 3

Konsep Kepercayaan Pelanggan

\begin{tabular}{|c|c|c|}
\hline NO & PENULIS & KONSEP \\
\hline 1. & Kotler \& Keller (2009) & $\begin{array}{l}\text { Memberikan pandangan pentingnya bagaimana } \\
\text { membangun kepercayaan, keyakinan pelanggan, } \\
\text { dan jika sudah demikian pelanggan akan dapat } \\
\text { sukarela mengikuti institusi pendidikan }\end{array}$ \\
\hline 2. & Morgan \& Hunt (1994 : 23) & $\begin{array}{l}\text { Kepercayaan terbentuk atau ada bila salah satu } \\
\text { pihak mempunyai keyakinan dan merasa aman } \\
\text { (confidence) atas integritas dan kehandalan } \\
\text { mitra pertukarannya }\end{array}$ \\
\hline 3. & $\begin{array}{l}\text { Moorman, Deshpande dan } \\
\text { Zaltman (1993) }\end{array}$ & $\begin{array}{l}\text { Kepercayaan didefinisikan sebagai kesediaan } \\
\text { untuk menyadarkan diri pada mitra pertukaran } \\
\text { di mana seseorang merasa yakin dan aman }\end{array}$ \\
\hline 4. & Rotter (1967) & $\begin{array}{l}\text { Kepercayaan adalah sebuah harapan yang } \\
\text { digeneralisasikan yang dipegang seseorang, } \\
\text { bahwa perkataan orang lain dapat diandalkan }\end{array}$ \\
\hline 5 & Mitchell dalam Egan (2001) & $\begin{array}{l}\text { Probity (focus kepada kepercayaan dan } \\
\text { integritas dan reputasi), Equity (berkaitan } \\
\text { dengan fair-mindedness, benevolence) dan } \\
\text { reliability (berkaitan dengan keandalan dan } \\
\text { ketepatan serta konsistensi dari produk atau } \\
\text { servis yang diharapkan dalam beberapa hal } \\
\text { berkaitan dengan garansi yang dikeluarkan oleh } \\
\text { institusi pendidikan) }\end{array}$ \\
\hline
\end{tabular}

\section{Definisi Operasional}

Kerelasian mempunyai dua unsur penting yakni kepercayaan dan komitmen. Kerelasian akan menciptakan kepercayaan dan komitmen yang pada akhirnya citra perusahaan akan terbangun. Seperti dikemukakan Kenna \& Assail (2000) yaitu "A Image is total perception of the subject that this fored by processing information from various sources over time". Citra merupakan keselurahan dari persepsi seseorang terhadap suatu hal yang dibentuk melalui proses informasi yang dilakukan dari berbagai sumber.

Selain berpengaruh terhadap citra, kerelasian pemasaran juga mempunyai pengaruh yang signifikan dan positif terhadap kepercayaan. Seperti hasil penelitian (Long Yi Lin dan Ching Luh Yu, 2009) ditemukan kerelasian pemasaran berpengaruh positif signifikan terhadap kepercayaan mahasiswa sebagai pelanggan (customer trust).

Sejalan dengan penelitian Long Yi Lin dan Ching Yuh Lu (2010) yang menyatakan bahwa citra institusi memiliki pengaruh yang signifikan terhadap kepercayaan mahasiswa. Dalam penelitian ini, kondisi yang sama diteliti pada hubungan antara citra institusi dengan kepercayaan mahasiswa. Kepercayaan mahasiswa pada perguruan tinggi dapat terbentuk jika perguruan tinggi dapat 
memberikan nilai pada produk/jasa yang diberikan.

Dalam kerangka operasionalisasi variabel penelitian ini, yaitu Kerelasian Pemasaran sebagai variabel bebas (X1) dan Citra Perguruan Tinggi sebagai variabel bebas (X2) yang akan mempengaruhi Kepercayaan Mahasiswa terhadap Perguruan Tinggi Program Diploma STIAMI sebagai variabel terikat $(\mathrm{Y})$, sebagaimana dalam tabel berikut ini:

Tabel 4

\section{Operasionalisasi Variabel}

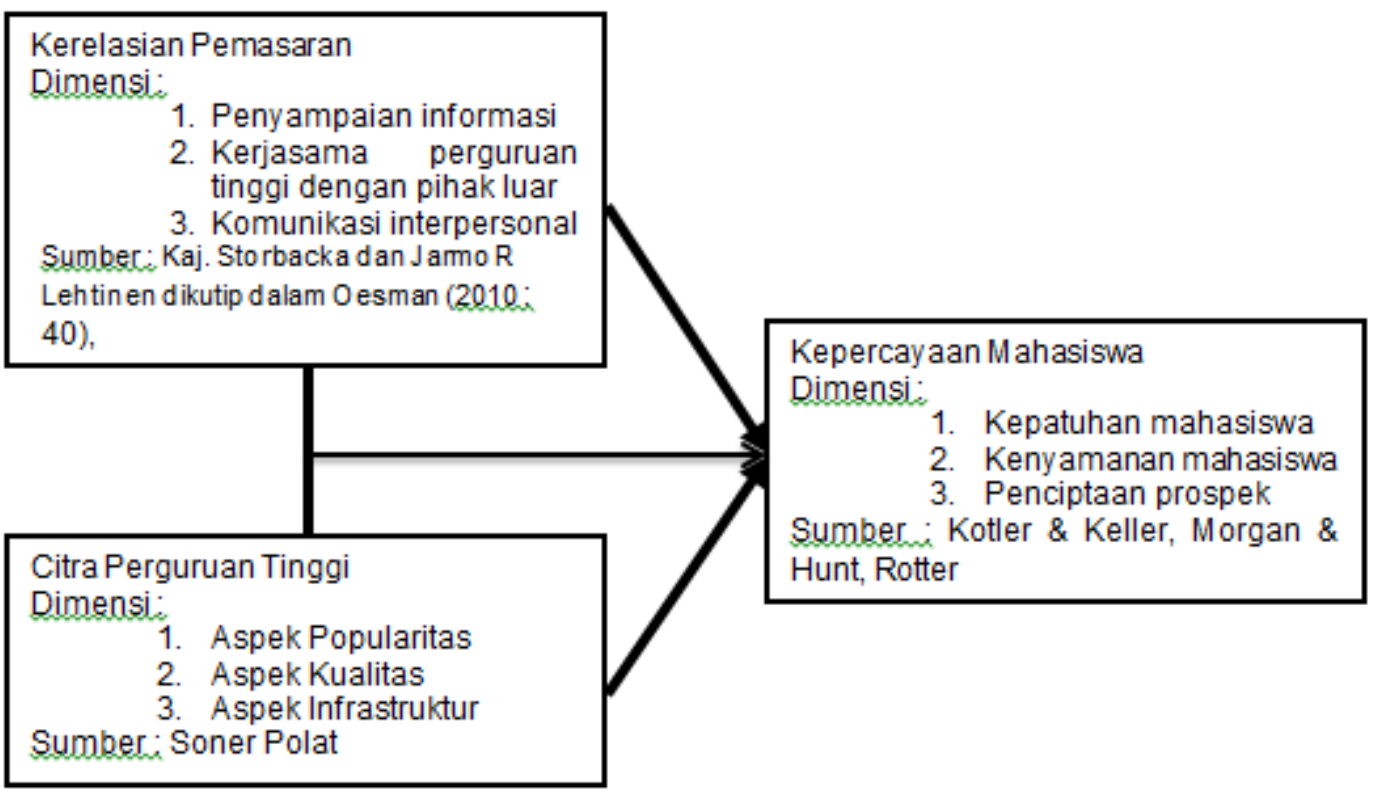

\section{Populasi dan Sampel}

Populasi pada penelitian ini yaitu mahasiswa aktif Program Diploma STIAMI semester Ganjil dan Genap Tahun Akademik 2013/2014 yang berjumlah 465 mahasiswa. Adapun besaran sampel dalam penelitian ini sebanyak 117 orang mahasiswa, dengan mengikuti kaidah bahwa apabila populasi kurang dari 100 lebih baik diambil semua hingga penelitiannya merupakan penelitian populasi. Jika jumlah subjeknya besar, sampel dapat diambil antara kisaran 10-15\% atau 20$25 \%$. Teknik pengambilan sampel pada penelitian ini adalah menggunakan teknik pengambilan sampel non probability sampling. Metode yang digunakan adalah metode accidental sampling (Santoso dan Tjiptono, 2001 : 80-90) yaitu hanya anggota populasi yang dijumpai secara kebetulan dan memenuhi kriteria sebagai sampel penelitian.

\section{Teknik Analisis Data}

Teknik analisis data yang digunakan dalam penelitian ini adalah sebagai berikut:

Uji Regresi Linier Berganda (Multiple Regression), dengan menggunakan rumus persamaan

$\mathrm{Y}=\mathrm{a}+\mathrm{b}_{1} \mathrm{X}_{1}+\mathrm{b}_{2} \mathrm{X}_{2}$

Keterangan:

$\mathrm{Y}=$ variabel dependen (nilai yang diprediksi)

$\mathrm{X}_{1}$ dan $\mathrm{X}_{2}=$ variabel independen

$\mathrm{a}=$ konstanta (nilai $\mathrm{Y}$ apabila $\mathrm{X}_{1}, \mathrm{X}_{2}=0$ )

$\mathrm{b}=$ koefisien regresi (nilai peningkatan atau penurunan)

Analisis korelasi berganda adalah untuk mengetahui derajat atau kekuatan hubungan antara tiga variabel atau lebih, serta untuk mengetahui kontribusi yang diberikan secara simultan oleh variabel $X_{1}$ dan $X_{2}$ terhadap nilai variabel $\mathrm{Y}$ dan konstribusi secara parsial yang diberikan oleh variabel $\mathrm{X}_{1}$ terhadap $\mathrm{Y}$ serta $\mathrm{X}_{2}$ terhadap $\mathrm{Y}$. Untuk menghitung nilai koefisien korelasi berganda digunakan rumus sebagai berikut: 
Nur Fitri Rahmawati, Pengaruh Kerelasian Pemasaran Dan Citra Perguruan Tinggi...

$\left(\mathrm{R}_{\mathrm{yX} 1 \times 2}\right)=\sqrt{\frac{\left(\mathrm{r}_{\mathrm{YX} 1}\right)^{2}+\left(\mathrm{r}_{\mathrm{YX} 2}\right)^{2}+2\left(\mathrm{r}_{\mathrm{YX} 1}\right)+\left(\mathrm{r}_{\mathrm{YX} 2}\right)+\left(\mathrm{r}_{\mathrm{X} 1 \mathrm{X} 2}\right)}{1-\left(\mathrm{r}_{\mathrm{X} 1 \mathrm{X} 2}\right)^{2}}}$

Keterangan:

$\mathrm{R}_{\mathrm{yx} 1 \times 2}=$ koefisien korelasi berganda

$\mathrm{X}_{1} \quad=$ Variabel bebas ke-1

$\mathrm{X}_{2} \quad$ = variabel bebas ke-2

$\mathrm{Y} \quad=$ variabel terikat

\section{Uji Koefisien Determinasi $\left(\mathbf{R}^{2}\right)$}

Koefisien determinasi $\left(\mathrm{R}^{2}\right)$ digunakan untuk mengukur seberapa besar variabelvariabel independen dapat menjelaskan variabel dependen. Koefisien ini menunjukan proporsi variabilitas total pada variabel dependen yang dijelaskan oleh model regresi. Nilai $R^{2}$ berada pada interval $0 \leq R^{2} \leq 1$.

Secara logika dapat diketahui bahwa makin baik estimasi model dalam menggambarkan data, maka makin dekat nilai $\mathrm{R}$ ke nilai 1 (satu). Nilai $\mathrm{R}^{2}$ dapat diperoleh dengan rumus :

$\mathrm{R}^{2}=(r)^{2} \times 100 \%$

Keterangan:

$\mathrm{R}^{2}=$ Koefisien determinasi

$\mathrm{r} \quad=$ Koefisien korelasi

\section{Uji t dan Uji F}

Untuk menguji koefisien regresi dilakukan pengujian secara parsial (Uji t) untuk melihat signifikansi dari pengaruh masing-masing variabel independent X1 terhadap Y dan X2 terhadap Y. pada Dasar pengambilan keputusan dengan taraf signifikansi alpha 0,05 . Pengujian ini dilakukan dengan asumsi bahwa variabelvariabel lain adalah nol. Kriteria pengujiannya sebagai berikut :

a. Jika $t_{\text {hitung }}>\mathrm{t}_{\text {tabel}}$, maka Ho ditolak dan H1 diterima

b. Jika $\mathrm{t}_{\text {hitung }}<\mathrm{t}_{\text {tabel}}$, maka Ho diterima dan H1 ditolak

Adapun Uji $\mathrm{F}$ digunakan untuk menguji apakah secara bersama-sama seluruh variabel bebas X1 dan X2 mwmpunyai pengaruh yang signifikan terhadap variabel terikat Y. Dasar pengambilan keputusan dengan taraf signifikansi alpha 0,05 dengan ketentuan sebagai berikut:

a. Jika $\mathrm{F}_{\text {hitung }}>\mathrm{F}$ tabel, maka Ho ditolak dan H1 diterima.

b. Jika $\mathrm{F}_{\text {hitung }}<\mathrm{F}_{\text {tabel, }}$, maka Ho diterima dan H1 ditolak.

\section{HASIL PENELITIAN}

\section{Uji Kualitas Data}

Sebelum menguji korelasi dan regresi, terlebih dahulu diuji Validitas dan Reliabilitas data seluruh variabel penelitian. Uji Validitas data ini dilakukan dengan bantuan program SPSS for Windows V.20 (hasil terlampir). Pada tabel berikut ini akan disajikan hasil uji validitas kuisioner dari ketiga variabel $\left(\mathrm{X}_{1}\right.$, $\mathrm{X}_{2}$, dan $\mathrm{Y}$ ). Validitas menunjukan kemampuan alat ukur atau instrument penelitian dalam mengukur suatu hal yang hendak didapatkan dari penggunaan instrument tersebut (Nugroho, 2011: 23).

\section{Tabel 5}

Hasil Uji Validitas Kuesioner Kerelasian Pemasaran

\begin{tabular}{|l|r|r|r|r|r|}
\hline \multicolumn{7}{|c|}{ Item Statistics } \\
\hline Pertanyaan & Mean & \multicolumn{1}{c|}{ r tabel } & Std. Deviation & \multicolumn{1}{c|}{$\mathrm{N}$} & Kesimpulan \\
\hline Skor_1.1 & 3.43 & 0.176 & .931 & 117 & Valid \\
Skor_1.2 & 3.44 & 0.176 & .700 & 117 & Valid \\
Skor_1.3 & 3.67 & 0.176 & .657 & 117 & Valid \\
Skor_2.1 & 3.40 & 0.176 & .720 & 117 & Valid \\
Skor_2.2 & 3.37 & 0.176 & .750 & 117 & Valid \\
Skor_3.1 & 3.97 & 0.176 & .642 & 117 & Valid \\
Skor_3.2 & 3.85 & 0.176 & .582 & 117 & Valid \\
Skor_3.3 & 3.69 & 0.176 & .688 & 117 & Valid \\
Skor_3.4 & 3.71 & 0.176 & .910 & 117 & Valid \\
Skor_3.5 & 3.74 & 0.176 & .672 & 117 & Valid \\
\hline Sumber- diolah dari hasil penelitian
\end{tabular}


Majalah Ilmiah Institut STIAMI

ISSN 1411-0830

Tabel 6

Hasil Uji Validitas Kuesioner Citra Perguruan Tinggi

\begin{tabular}{|l|r|r|r|r|r|}
\hline Pertanyaan & Mean & \multicolumn{1}{|c|}{$\mathrm{r}_{\text {tabel }}$} & Str. Deviation & $\mathrm{N}$ & Kesimpulan \\
\hline Skor_1.1 & 3.60 & 0.176 & .644 & 117 & Valid \\
Skor_1.2 & 3.72 & 0.176 & .655 & 117 & Valid \\
Skor_1.3 & 3.71 & 0.176 & .603 & 117 & Valid \\
Skor_1.4 & 3.72 & 0.176 & .741 & 117 & Valid \\
Skor_2.1 & 4.06 & 0.176 & .647 & 117 & Valid \\
Skor_2.2 & 3.61 & 0.176 & .669 & 117 & Valid \\
Skor_2.3 & 3.21 & 0.176 & .836 & 117 & Valid \\
Skor_3.1 & 2.86 & 0.176 & .829 & 117 & Valid \\
Skor_3.2 & 2.54 & 0.176 & .996 & 117 & Valid \\
Skor_3.3 & 2.43 & 0.176 & .874 & 117 & Valid \\
Skor_3.4 & 2.74 & 0.176 & .745 & 117 & Valid \\
Skor_3.5 & 2.72 & 0.176 & .786 & 117 & Valid \\
\hline
\end{tabular}

Tabel 7

Hasil Uji Validitas Kuesioner Kepercayaan Mahasiswa

\begin{tabular}{|l|r|r|r|r|r|}
\hline \multicolumn{7}{|c|}{ Item Statistics } \\
\hline Pertanyaan & Mean & \multicolumn{1}{c|}{$\mathrm{r}_{\text {tasel }}$} & Std. Deviation & \multicolumn{1}{c|}{$\mathrm{N}$} & Kesimpulan \\
\hline Skor_1.1 & 4.43 & 0.176 & .686 & 117 & Valid \\
Skor_1.2 & 4.21 & 0.176 & .641 & 117 & Valid \\
Skor_1.3 & 4.38 & 0.176 & .774 & 117 & Valid \\
Skor_2.1 & 3.55 & 0.176 & .905 & 117 & Valid \\
Skor_2.2 & 3.54 & 0.176 & .726 & 117 & Valid \\
Skor_2.3 & 2.93 & 0.176 & .763 & 117 & Valid \\
Skor_2.4 & 3.41 & 0.176 & .632 & 117 & Valid \\
Skor_2.5 & 3.64 & 0.176 & .675 & 117 & Valid \\
Skor_3.1 & 3.50 & 0.176 & .988 & 117 & Valid \\
Skor_3.2 & 3.74 & 0.176 & 1.027 & 117 & Valid \\
Sumber; diolah darihasil penelitian
\end{tabular}

Dengan melihat tabel di atas, dapat diketahui bahwa hasil uji validitas data menunjukan semua butir pertanyaan valid, karena nilai $r_{\text {hitung }}$ lebih besar dari $r_{\text {tabel }}=$ 0,176 . Dengan demikian dapat dikatakan bahwa semua pertanyaan dalam kuisioner semua variabel adalah valid, artinya pertanyaan-pertanyaan tersebut dapat dijadikan instrument penelitian.

Adapun hasil Uji Reliabilitas variabel Kerelasian Pemasaran, Citra Perguruan Tinggi terhadap Kepercayan Mahasiswa dilakukan dengan bantuan program SPSS for Windows V.20 (hasil terlampir) dan dapat dilihat pada tabel berikut:

Tabel 8

Hasil Uji Reliabilitas

\begin{tabular}{|l|r|r|r|}
\hline \multicolumn{5}{|c|}{ Reliability Statistics } \\
\hline Variabel & Cronbach's Alpha & N of Items & Kesimpulan \\
\hline Kerelasian Pemasaran & .764 & 10 & Reliabel \\
\hline Citra Perguruan Tinggi & .809 & 12 & Reliabel \\
\hline Kepercayaan Mahasiswa & .616 & 10 & Reliabel \\
\hline
\end{tabular}


Nur Fitri Rahmawati, Pengaruh Kerelasian Pemasaran Dan Citra Perguruan Tinggi...

Dari tabel data di atas diketahui bahwa koefisien reliabilitas alpha untuk variabel Kerelasian Pemasaran $\left(\mathrm{X}_{1}\right)$ diperoleh sebesar 0,764 lebih besar dari angka penguji yaitu 0,60, maka hasil pengujian reliabilitas pada variabel Kerelasian Pemasaran dapat dinyatakan reliable atau dapat diandalkan. Koefisien reliabilitas alpha untuk variabel Citra Perguruan Tinggi $\left(\mathrm{X}_{2}\right)$ diperoleh sebesar 0,809 lebih besar dari angka penguji 0,60 maka hasil pengujian reliabilitas pada variabel Citra Perguruan Tinggi dapat dinyatakan reliable. Sedangkan reliabilitas alpha untuk variabel Kepercayaan Mahasiswa (Y) diperoleh sebesar 0,616 lebih besar dari angka penguji 0,60 maka hasil pengujian reliabilitas pada variabel tersebut dinyatakan reliable atau dapat diandalkan. Interpretasinya, hasil reliable ini bermakna bahwa indikatorindikator penelitian yang dipergunakan sebagai alat ukur dapat diandalkan untuk mengukur masing-masing variabelnya.

\section{Pengujian Kriteria Statistik}

Uji Signifikansi Korelasi Product Moment Sederhana (Uji t) Pada Variabel Bebas Kerelasian Pemasaran (X1) Terhadap Variabel Terikat Kepercayaan Mahasiswa (Y)

Tabel 9

Hasil Uji t Kerelasian Pemasaran

\begin{tabular}{|c|c|c|c|c|c|c|}
\hline \multicolumn{7}{|c|}{ Coefficients $^{a}$} \\
\hline \multirow{2}{*}{\multicolumn{2}{|c|}{ Model }} & \multicolumn{2}{|c|}{$\begin{array}{l}\text { Unstandardized } \\
\text { Coefficients }\end{array}$} & \multirow{2}{*}{\begin{tabular}{|c} 
Standardized \\
Coefficients \\
Beta \\
\end{tabular}} & \multirow[t]{2}{*}{$\mathrm{t}$} & \multirow[t]{2}{*}{ Sig. } \\
\hline & & B & Std. Error & & & \\
\hline \multirow{2}{*}{1} & (Constant) & 23.398 & 2.795 & & 8.373 & .000 \\
\hline & Kerelasian_Pemasaran & .384 & .077 & .424 & 5.016 & .000 \\
\hline
\end{tabular}

Terlihat pada hasil uji parsial tabel diatas diperoleh thitung untuk variable Kerelasian Pemasaran sebesar 5,016. Dengan derajat kebebasan $(\mathrm{df})=\mathrm{n}-2=117-2=115$, dengan demikian kriteria pengambilan keputusannya adalah : karena $t_{\text {hitung }} 5,016>$ $t_{\text {tabel }}$ 1,980, sehingga $\mathrm{H}_{0}$ ditolak dan $\mathrm{H}_{1}$ diterima secara parsial (sendiri-sendiri) kerelasian pemasaran $\left(\mathrm{X}_{1}\right)$ mempengaruhi kepercayaan mahasiswa (Y).

\section{Uji $\mathbf{R}^{2}$ dan Adjusted $\mathbf{R}^{2}$ Kerelasian Mahasiswa (X1) Terhadap Kepercayaan Mahasiswa (Y)}

Tabel 10

Koefisien Korelasi Kerelasian Pemasaran (X1) terhadap Y

\begin{tabular}{|l|c|r|r|r|}
\hline \multicolumn{5}{|c|}{ Model Summary } \\
\hline Model & $R$ & R Square & $\begin{array}{c}\text { Adjusted R } \\
\text { Square }\end{array}$ & $\begin{array}{c}\text { Std. Error of } \\
\text { the Estimate }\end{array}$ \\
\hline 1 & $.424^{\circ}$ & .179 & .172 & 3.418 \\
\hline
\end{tabular}

Berdasarkan hasil output spss 20 tabel diatas nilai $\mathrm{R}$ sebesar 0,424 artinya kerelasian pemasaran mempunyai hubungan yang sedang terhadap Kepercayaan mahasiswa. Maka nilai $\mathrm{R}$ Square atau $\mathrm{R}^{2}$ (Koefisien
Determinasi) hasil regresinya adalah R Square sebesar 0,179, hasil tersebut menunjukkan bahwa pengaruh kerelasian pemasaran terhadap kepercayaan mahasiswa hanya sebesar R Square 17,9 \%. Sedangkan sisanya 
Majalah Ilmiah Institut STIAMI

ISSN 1411-0830

sebesar 82,1\% merupakan nilai yang dapat dipengaruhi oleh variable-variabel lainnya yang tidak diteliti.
Uji Signifikansi Korelasi Product Moment Sederhana (Uji t) Pada Variabel Bebas Citra Perguruan Tinggi (X2) Terhadap Variabel Terikat Kepercayaan Mahasiswa (Y)

Tabel 11

Hasil Uji t Citra Perguruan Tinggi

\begin{tabular}{|c|c|c|c|c|c|}
\hline \multicolumn{6}{|c|}{ Coefficients ${ }^{2}$} \\
\hline \multirow[t]{2}{*}{ Model } & \multicolumn{2}{|c|}{$\begin{array}{c}\text { Unstandardized } \\
\text { Coefficients }\end{array}$} & $\begin{array}{l}\text { Standardized } \\
\text { Coefficients }\end{array}$ & \multirow[t]{2}{*}{$\mathrm{t}$} & \multirow[t]{2}{*}{ Sig. } \\
\hline & $\mathrm{B}$ & Std. Error & Beta & & \\
\hline (Constant) & 23.090 & 2.292 & & 10.072 & .000 \\
\hline Citra_Perguruan_Tinggi & .366 & .058 & .504 & 6.264 & .000 \\
\hline
\end{tabular}

Terlihat pada hasil uji parsial tabel diatas diperoleh $t_{\text {hitung }}$ untuk variable Citra Perguruan Tinggi sebesar 6,264. Dengan derajat kebebasan (df) $=n-2=117-2=$ 115 , dengan demikian kriteria pengambilan keputusannya adalah : karena $t_{\text {hitung }} 6,264>$ $t_{\text {tabel }} 1,980$, sehingga $\mathrm{H}_{0}$ ditolak dan $\mathrm{H}_{1}$ diterima secara parsial (sendiri-sendiri) citra perguruan tinggi $\left(\mathrm{X}_{2}\right)$ mempengaruhi kepercayaan mahasiswa (Y).

Uji $\mathbf{R}^{\mathbf{2}}$ dan Adjusted $\mathbf{R}^{\mathbf{2}}$ Citra Perguruan Tinggi (X2) Terhadap Kepercayaan Mahasiswa (Y)

Tabel 12

Koefisien Korelasi Citra Perguruan Tinggi (X2) terhadap Y

\begin{tabular}{|l|r|r|r|r|}
\hline Model & $\mathrm{R}$ & R Square & $\begin{array}{c}\text { Adjusted R } \\
\text { Square }\end{array}$ & $\begin{array}{c}\text { Std. Error of } \\
\text { the Estimate }\end{array}$ \\
\hline 1 & $.504^{\mathrm{a}}$ & .254 & \multicolumn{3}{|c|}{.248} & 3.2586 \\
\hline
\end{tabular}

Berdasarkan hasil output spss 20 tabel diatas nilai $\mathrm{R}$ sebesar 0,504 artinya citra perguruan tinggi mempunyai hubungan yang sedang terhadap Kepercayaan mahasiswa. Maka nilai R Square atau R2 (Koefisien Determinasi) hasil regresinya adalah $\mathrm{R}$ Square sebesar 0,254, hasil tersebut menunjukkan bahwa pengaruh citra perguruan tinggi
Tabel 13

terhadap kepercayaan mahasiswa hanya sebesar R Square 25,4\%. Sedangkan sisanya sebesar 74,6\% merupakan nilai yang dapat dipengaruhi oleh variable-variabel lainnya yang tidak diteliti.

\section{Uji Signifikansi Korelasi Product Moment} Ganda (Uji F)

\section{Hasil Uji F}

ANOVA $=$

\begin{tabular}{|rl|r|r|r|r|r|}
\hline Model & \multicolumn{1}{c|}{$\begin{array}{c}\text { Sum of } \\
\text { Squares }\end{array}$} & \multicolumn{1}{c|}{ df } & Mean Square & F & Sig. \\
\hline \multirow{2}{*}{1} & Regression & 442.930 & 2 & 221.465 & 21.132 & $.000^{\circ}$ \\
& Residual & 1194.728 & 114 & 10.480 & & \\
& Total & 1637.658 & 116 & & & \\
\hline
\end{tabular}

a. Dependent Variable: Kepercayaan Mahasiswa

b. Predictors: (Constant), Citra_Perguruan_Tinggi, Kerelasian_Pemasaran 
Nur Fitri Rahmawati, Pengaruh Kerelasian Pemasaran Dan Citra Perguruan Tinggi...

Terlihat pada tabel diatas nilai $\mathrm{f}_{\text {hitung }}$ sebesar 21,132. Pada taraf signifikansi 5\% $(0,000<$ $0,05)$ diperoleh $\mathrm{F}_{\text {tabel }}=3,08(21,132>3,08)$, maka $\mathrm{H}_{0}$ ditolak dan $\mathrm{H}_{1}$ diterima sehingga dapat dikatakan bahwa pemasaran $\left(\mathrm{X}_{1}\right)$ dan Citra Perguruan Tinggi $\left(\mathrm{X}_{2}\right)$ berpengaruh secara bersama-sama terhadap kepercayaan Mahasiswa (Y).

Model Persamaan Regresi Berganda Antara Kerelasian Pemasaran dan Citra Perguruan Tinggi Terhadap Kepecayaan Mahasiswa

Tabel 14

Model Persamaan Regresi Berganda

\begin{tabular}{|c|c|c|c|c|c|c|}
\hline \multicolumn{7}{|c|}{ Coefficients ${ }^{2}$} \\
\hline \multirow{2}{*}{\multicolumn{2}{|c|}{ Model }} & \multicolumn{2}{|c|}{$\begin{array}{l}\text { Unstandardized } \\
\text { Coefficients }\end{array}$} & \multirow{2}{*}{$\begin{array}{l}\text { Standardized } \\
\text { Coefficients } \\
\text { Beta }\end{array}$} & \multirow[t]{2}{*}{$\mathrm{t}$} & \multirow[t]{2}{*}{ Sig. } \\
\hline & & $B$ & Std. Error & & & \\
\hline \multirow{3}{*}{1} & (Constant) & 20.662 & 2.744 & & 7.529 & .000 \\
\hline & Kerelasian_Pemasaran & .151 & .095 & .167 & 1.586 & .116 \\
\hline & Citra_Perguruan_Tinggi & .287 & .076 & .396 & 3.770 & .000 \\
\hline
\end{tabular}

Setelah angka yang terdapat ditabel coefficients dimasukkan kedalam persamaan regresi linear berganda, maka di dapat rumus persamaan regresi linear berganda sebagai berikut:

$Y=20,662+0,151 X_{1}+0,287 X_{2}$

Berdasarkan rumusan persamaan regresi linear berganda diatas, maka dapat ditunjukkan koefisien regresi sebagai berikut :

1) Koefisien regresi X1 (Kerelasian Pemasaran)

Besarnya koefisien regresi adalah 0,151 yang menyatakan bahwa jika kerelasian pemasaran bertambah sebesar 1 poin, maka kepercayaan mahasiswa akan mengalami peningkatan sebesar 0,151. Dengan asumsi tidak ada penambahan konstanta nilai citra perguruan tinggi.

2) Koefisien regresi X2 (Citra Perguruan Tinggi)

Besarnya koefisien regresi adalah 0,287 menyatakan bahwa jika citra perguruan tinggi bertambah sebesar 1 poin, maka kepercayaan mahasiswa akan mengalami peningkatan sebesar 0,287. Dengan asumsi tidak ada penambahan konstanta nilai kerelasian pemasaran.

\section{PEMBAHASAN}

Berdasarkan pengujian hipotesis di atas, maka terdapat beberapa hal yang perlu diuraikan sehubungan dengan pemecahan masalah.

1) Kerelasian Pemasaran Program Diploma STIAMI di Jakarta

Berdasarkan angka rata-rata penafsiran yang diperoleh yaitu $\mathrm{M}=3,62$ maka dapat dikatakan bahwa Kerelasian Pemasaran Program Diploma STIAMI tergolong baik namun harus ditingkatkan. Peningkatan kerelasian pemasaran sangat diperlukan terutama pada kerjasama pemagangan dan penyerapan lulusan.

2) Citra Perguruan Tinggi Program Diploma STIAMI di Jakarta

Berdasarkan angka rata-rata penafsiran yang diperoleh yaitu $\mathrm{M}=3,24$ maka dapat dikatakan bahwa Citra Perguruan Tinggi Program Diploma STIAMI tergolong 
cukup baik. Hal ini menunjukan bahwa Diploma STIAMI masih memiliki citra yang cukup baik di mata mahasiswanya. Walaupun demikian, Diploma STIAMI tetap harus membuat citra institusi menjadi lebih baik lagi demi meningkatkan kepercayaan mahasiswanya. Beberapa diantaranya yaitu kesesuaian biaya dengan manfaat yang didapat oleh mahasiswa, keadaan gedung, ruang perpustakaan, kelengkapan buku perpustakaan, kelengkapan ruang lab, dan tempat parkir.

3) Kepercayaan Mahasiswa Program Diploma STIAMI di Jakarta

Berdasarkan angka rata-rata penafsiran yang diperoleh yaitu $\mathbf{M}=3,34$ maka disimpulkan bahwa kepercayaan mahasiswa tergolong cukup tinggi. Untuk itu, STIAMI harus meningkatkan kepercayaan mahasiswa dengan cara memberikan kenyamanan mahasiswa dalam berinteraksi dengan staf administrasi, proses belajar mengajar dikelas yang baik, sehingga dengan adanya peningkatkan tersebut maka mereka akan merekomendasikan teman/kerabat untuk kuliah di STIAMI baik yang kuliah D3 maupun yang sedang melanjutkan ke jenjang yang lebih tinggi.

\section{Pengaruh Kerelasian Pemasaran dan Citra Perguruan Tinggi secara parsial dan simultan terhadap Kepercayaan Mahasiswa Program Diploma STIAMI di Jakarta}

1) Pengaruh Kerelasian Pemasaran terhadap Kepercayaan Mahasiswa Program Diploma STIAMI di Jakarta

Dari hasil uji parsial diperoleh $\mathrm{t}_{\text {hitung }}$ untuk variable $X_{1}$ sebesar 5,016. Dengan derajat kebebasan $(\mathrm{df})=\mathrm{n}-2=117-2=115$, dengan demikian kriteria pengambilan keputusannya adalah : karena $t_{\text {hitung }} 5,016$ $>t_{\text {tabel }} 1,980$, sehingga $\mathrm{H}_{0}$ ditolak dan $\mathrm{H}_{1}$ diterima secara parsial (sendiri-sendiri) kerelasian pemasaran $\left(\mathrm{X}_{1}\right)$ mempengaruhi kepercayaan mahasiswa (Y).
2) Pengaruh Citra Perguruan Tinggi terhadap Kepercayaan Mahasiswa Program Diploma STIAMi di Jakarta Dari hasil uji parsial diperoleh $t_{\text {hitung }}$ untuk variable $\mathrm{X}_{2}$ sebesar 6,264. Dengan derajat kebebasan $(\mathrm{df})=\mathrm{n}-2=117-2=115$, dengan demikian kriteria pengambilan keputusannya adalah : karena $t_{\text {hitung }} 6,264$ $>t_{\text {tabel }} 1,980$, sehingga $\mathrm{H}_{0}$ ditolak dan $\mathrm{H}_{1}$ diterima secara parsial (sendiri-sendiri) citra perguruan tinggi $\left(\mathrm{X}_{2}\right)$ mempengaruhi kepercayaan mahasiswa (Y).

3) Pengaruh Kerelasian Pemasaran dan Citra Perguruan Tinggi bersama-sama terhadap Kepercayaan Mahasiswa

Dari hasil uji simultan nilai $\mathrm{f}_{\text {hitung }}$ sebesar 21,132. Pada taraf signifikansi 5\% $(0,000$ $<0,05)$ diperoleh $\mathrm{F}_{\text {tabel }}=3,08(21,132>$ 3,08), maka $\mathrm{H}_{0}$ ditolak dan $\mathrm{H}_{1}$ diterima sehingga dapat dikatakan bahwa kerelasian pemasaran $\left(\mathrm{X}_{1}\right)$ dan Citra Perguruan Tinggi $\left(\mathrm{X}_{2}\right)$ berpengaruh terhadap kepercayaan Mahasiswa (Y).

\section{SIMPULAN}

Berdasarkan deskripsi, analisis hasil penelitian dan pembahasan, dapat ditarik beberapa kesimpulan sebagai berikut:

(1) Tanggapan responden mengenai berbagai aspek dari kerelasian pemasaran, secara keseluruhan menunjukkan bahwa aspek kemudahan akses informasi melalui website, informasi kalender akademik, keobjektifan nilai, kedekatan mahasiswa dengan dosen, suasana belajar, kedekatan mahasiswa dengan staf administrasi, keadilan yang sama dan keramahan dinilai baik oleh mahasiswanya. Namun aspek kerjasama Diploma STIAMI dengan pihak luar berkaitan dengan kerjasama pemagangan dan penyerapan lulusan masih dinilai cukup baik.

(2) Dari hasil penelitian diketahui bahwa variabel citra perguruan tinggi berkaitan dengan kredibilitas Diploma STIAMI, Reputasi Diploma STIAMI, prestasi 
Nur Fitri Rahmawati, Pengaruh Kerelasian Pemasaran Dan Citra Perguruan Tinggi...

mahasiswa, kepedulian Diploma STIAMI, kualitas dosen mengajar, kualitas pelayanan staf administrasi dinilai baik oleh mahasiswanya. Sedangkan untuk kesesuaian biaya dengan manfaat yang didapat, keadaan gedung, ruang perpustakaan, kelengkapan buku perpustakaan, kelengkapan ruang lab dan tempat parkir masih dinilai kurang baik oleh mahasiswa Diploma STIAMI.

(3) Dan tanggapan responden tentang kepercayaan mahasiswa yang meliputi aspek mengikuti peraturan, ketepatan kehadiran, mengikuti anjuran dosen, kenyamanan dalam mengikuti perkuliahan, kecukupan jumlah ruang kelas dengan jumlah mahasiwa dinilai tinggi oleh mahasiswa Diploma STIAMI, dan untuk penciptaan prospek seperti merekomendasikan teman/kerabat dan melajutkan studi ke jenjang yang lebih tinggi di Diploma STIAMI masih dinilai rendah.

(4) Dari hasil penelitian diketahui bahwa terdapat pengaruh yang positif dan signifikan kerelasian pemasaran terhadap kepercayaan mahasiswa Diploma STIAMI di Jakarta sebesar 0,179. Citra Perguruan Tinggi berpengaruh terhadap kepercayaan mahasiswa sebesar 0,254. Sedangkan pengaruh kerelasian pemasaran dan citra perguruan tinggi secara simultan terhadap kepercayaan mahasiswa Diploma STIAMI di Jakarta adalah sebesar 0,270. Dari penelitian tersebut didapat variabel citra perguruan tinggi memiliki pengaruh lebih besar terhadap kepercayaan mahasiswa.

\section{SARAN}

Berdasarkan kesimpulan di atas dengan mempertimbangkan tujuan penelitian yang ada, maka peneliti mengajukan saran-saran yang diharapkan mendapat perhatian dari pihak terkait dengan pengelola pendidikan tinggi jenjang Diploma di perguruan tinggi STIAMI sebagai berikut:

(1) Kerelasian pemasaran yang baik akan dapat meningkatkan hubungan jangka panjang yang berdampak kepada kepercayaan mahasiswa dalam hal ini Diploma STIAMI harus menambah dan mensosialisasikan kerjasama pemagangan dengan perusahaanperusahaan atau pihak luar.

(2) Pengelolaan Citra Perguruan Tinggi harus mampu dilakukan oleh Diploma STIAMI agar dapat memberikan pelayanan yang baik kepada mahasiswa. STIAMI Program Diploma perlu fokus terhadap insfrastruktur baik gedung, ruang perpustakaan, ruang lab, kelengkapan buku-buku perpustakaan, kelengkapan ruang lab, dan tempat parkir.

(3) Kepercayaan mahasiswa harus dibangun oleh setiap perguruan tinggi termasuk program Diploma STIAMI dalam hal memberikan pelayanan yang terbaik pada mahasiswa.

(4) Diploma STIAMI harus mampu membangun citra yang baik di mata mahasiswa agar memanamkan kepercayaan kepada mahasiswa

(5) Proses belajar mengajar perlu ditingkatkan agar mahasiswa mendapatkan manfaat yang lebih luas.

(6) Menambah jumlah buku di perpustakaan. Buku-buku edisi terbaru harus banyak dikoleksi mengingat cepat dan pesatnya perkembangan ilmu pengetahuan.

(7) Membangun lahan parkir dikarenakan terbatasnya lahan yang dimiliki Diploma STIAMI saat ini dan bertambahnya jumlah mahasiswa Diploma STIAMI yang menggunakan kendaraan bermotor.

(8) Kelengkapan ruang lab yang harus difasilitas guna menunjang kegiatan proses belajar mengajar.

\section{DAFTAR PUSTAKA}

\section{Buku}

Ardianto, Elvinaro dan Soemirat, Soleh. 2004. Dasar-Dasar Public Relations. Cetakan Ketiga. Bandung : Remaja Rosdakarya. 
Arikunto, S. 2010. Prosedur penelitian : Suatu Pendekatan Praktik. (Edisi Revisi). Jakarta : Rineka Cipta

Badri, Sofwan. 1999. Konsep-Konsep Dasar Administrasi, Administrasi Negara dan Administrasi Pembangunan. Jakarta : PT. Bina Aksara.

Basu, Swasta dan Irawan. 2008. Manajemen Pemasaran Modern. Yogyakarta : Liberty

Buchari, Alma. 2009. Manajemen Pemasaran dan Pemasaran Jasa. Bandung : Alfabeta.

Bruhn, Manfred. 2006. Relationship Marketing : Management of Customer Relationship. England : Harlow

Donaldson, Bill and Tom O'Toole. 2002. Strategic Market Relationship : From Strategy to Implementation. New York : John Wiley and Sons

Egan, John. 2001. Relationship Marketing, Exploring Relational Strategies in Marketing. 1st edition. Prentice Hall.

Gaffar, Vanessa. 2007. CRM dan MPR Hotel (Customer Relationship Management and Marketing Public Relations). Bandung : Alfabeta.

Gregory, R. James and Jack G. Wiechmann. 2000. Marketing Corporate Image, Second Edition, Megraw-Hill Professional.

Gummesson, Evert. 2002. Total Relationship Marketing. Second Edition. Elsevier Ltd, Ohio.

Hasibuan, Malayu S. P. 2008. Manajemen Sumber Daya Manusia. Jakarta : PT. Bumi Aksara.
Husein, Umar. 2008. Desain Penelitian MSDM dan Perilaku Karyawan. Seri Desain Penelitian Bisnis - No 1. Jakarta : PT Rajagrafindo Persada

Hollesen, Svend. 2003. Marketing Management A Relationship Approach, Pearson Education Limited. New Jersey : Prentice Hall Inc.

Irawan, Prasetya. 1997. Logika dan Prosedur Penelitian. Jakarta : STIA LAN Press.

Isyanto, P., Hersona, S., dan Darmawan, R. 2012. Analisis Citra Merek Produk Im3 : Studi Kasus pada Mahasiswa Fakultas Ekonomi Universitas Singaperbangsa. Karawang. BPFE Unsika. I (I); 1-9

Kotler, Philip. 2006. Manajemen Pemasaran. Edisi 11. Jakarta: PT. Indeks

Pemasaran. Jakarta : Erlangga

\begin{tabular}{lcr} 
& .2012. & Marketing \\
\hline Management & Edisi 14, & Global \\
Edition.Pearson Prentice Hall &
\end{tabular}

Manullang. 2008. Manajemen Personalia. Jakarta : PT. Ghalia Indonesia.

Narimawati. Umi. 2008. Metodologi Penelitian Kualitatif dan Kuantitatif, Teori dan Aplikasi. Bandung : Agung Media

Oesman, Marty Yevis, 2010, Sukses Mengelola Marketing Mix, CRM, Customer Value, dan Customer Dependency (Kasus Pada Pemasaran Shopping Center), diakes tanggal 15 Oktober 2010

Palmer, Adrian. 2001. Principles of Service Marketing.Second edition.McGraw-Hill Higher Education. England 
Nur Fitri Rahmawati, Pengaruh Kerelasian Pemasaran Dan Citra Perguruan Tinggi...

Ruslan, Rosady. 2008. Manajemen Public Relatoins \& Media Komunikasi. Jakarta : PT Rajagrafindo Persada.

Santoso, Singgih \& Fandy Tjiptono, 2001. Riset Pemasaran, Konsep dan Aplikasi dengan SPSS. Jakarta : PT. Alex Media Komputindo

Siagian, Sondang P. 2009. Manajemen Sumber Daya Manusia. Jakarta : Bumi Aksara.

2011. Filsafat Administrasi (Edisi Revisi). Jakarta : Bumi Aksara.

Siregar, Sofyan. 2010. Statistika Deskriptif untuk Penelitian. Jakarta : Rajawali Pers

Solomon, M. R. 2007. Consumer Behavior: Buying, Having, and Being. New Jersey, Upper Saddle River: Pearson Educatio n, Inc.

Sutisna. 2001, Perilaku Konsumen dan Komunikasi Pemasaran. Cetakan I. Bandung : Penerbit PT. Remaja Rosdakarya.

Suganda, Dann. 1991. Administrasi Strategi, Taktik dan Teknik Penciptaan Efisiensi. Jakarta : Intermedia.

Sugiyono. 2009. Metode Penelitian Kuantitatif dan Kualitatif. Bandung : CV.Alfabeta
Sutojo, Siswanto, 2004. Membangun Citra Perusahaan. Jakarta : PT Damar Mulia Pustaka.

Temporal, Paul, Martin Trott. 2002. Memaksimalkan Nilai Merek Melalui Kekuatan Relationship Management. Jakarta : Salemba Empat.

Tiwana, Amrit. 2009. The Knowledge Management Toolkit : Essentials of System Analysis \& Design.

Tjiptono, Fandy. 2005. Pemasaran Jasa. Yogyakarta : Bayu Media Publishing.

Yazid, 2005. Pemasaran Jasa; Konsep dan Implementasi. Edisi Kedua. Yogyakarta : Ekonisia Fakultas Ekonomi UII

\section{Jurnal}

Puji Isyanto, H. Sonny Hersona, Rama Darmawan. 2012. Analisis Citra Merek Produk IM3: Studi Kasus pada Mahasiswa Fakultas Ekonomi Universitas Singaperbangsa. Karawang : Vol.1 No. 1, BPFE, Unsika.

Polat, Soner and Tugba Hezer. 2011.Relation Between Organizational Image and Organizational Trust in Educational Organizations. International Journal of Education Administration and Policy Studies Vol 3 (9). 